\title{
Impact of Applying Guidelines on Nurses`Perception about Negative Aspect Regarding the Use of Technological Devices in Critical Care
}

\author{
Lara Adel, Magda Mohamed ,Mamdouh Mohammed, Dina sobh \\ Clinical instructor at health technical institute in port said, professor of medical-surgical \\ nursing, in Faculty of Nursing at Ain Shams University, professor of general and \\ vascular surgery, in Faculty of Medicine at Suez Canal University, Lecture of medical- \\ surgical nursing, in Faculty of Nursing at Port Said University.
}

\begin{abstract}
BackGround: Technology is the practical application of knowledge, especially in a particular area (ICU). A Quasi-experimental design was used to evaluate the impact of applying guidelines on nurses' perception regarding negative aspect of using technological devices in critical care units. It was conducted in critical care units of Port-Said General Hospital, El- Zohoor Hospital, Port-Foad Hospital, El-Mabarrah Hospital (Health insurance) and El-Tadamon Hospital. The study samples consisted of 112 nurses working in the previous mentioned settings. The data was collected through a structured questionnaire to assess nurses perception about negative aspects of using technological devices in critical care units. The results revealed that the nurses' perception regarding the negative aspects increased when compared between preintervention $(5.4 \%)$, post-intervention $(83.9 \%)$ and follow up $(84.8 \%)$ with high statistically significant difference as $(\mathrm{p}=0.000)$. In multivariate analysis, the model explains $41 \%$ of the change in nurse's perception in related to negative aspects after intervention. It could conclude that, educational guidelines would be benefits. The study recommended different strategies for nursing practice to enhance nurses` perception regarding use of technological devices in critical care such as handout with Arabic language including comprehensive information about all aspects of technologies.
\end{abstract}

Key Words: Critical care unit - Guidelines- perception - negative aspect-Technology 


\section{INTRODUCTION}

Technology is improving patients' experience and care at hospitals every day. Facilities can take advantage of many different options to boost outcomes and satisfaction, especially regarding some of its most vulnerable patients in intensive care (Puri, Puri, \& Dellinger, 2009; White, 2016).

Critical care units are a specialized section of a hospital that provides comprehensive and continuous care for persons who are critically ill. The intensive care units (ICU) environment is a stressful one for patients. The presence of strange machinery, loud and unfamiliar noises, separation from family, and immobility contribute to make this a stressful environment (Pang, $\boldsymbol{\&}$ Suen, 2008; Sole, Klein, \& Moseley, 2013).

The Institute of Medicine (IOM) suggests that quality health care must be safe, patientcentered, timely, efficient, effective, and equitable. These goals for excellence in health care help guide the use and development of technology in the acute and critical care setting (Elizabeth, 2010).

Perception is defined as the conscious recognition and interpretation of sensory stimuli that serve as a basis for understanding, learning, and knowing for motivating a particular action or reaction or product of the act of perceiving (Hweidi, 2007). Moreover, perception is awareness, comprehension or an understanding of something easily (Webster, 2016).

\section{Significant of the study:}

The importance of the present study was to improved nurses' perception in the Critical Care Units regarding the use of technological devices through applying guidelines to help them enforce on negative aspects effects in order to keep the patient with optimal health status. For this aim, the current study was done.

\section{AIM OF STUDY:}

This study aims to: Evaluate the impact of applying guidelines on nurses' perception on negative aspects regarding the use of technological devices in critical care units. Through:

a) Develop the guidelines on nurses perception regarding negative aspects of using technological devices in critical care units based on the needs.

b) Implement the guidelines on nurses perception regarding negative aspects of using technological devices in critical care units.

c) Evaluate the impact of implementing guidelines on nurse's perception of negative aspect immediately and follow-up after three months of implementation. 
Research questions: To achieve the aim of this study، the following research questions were formulated:

1. What is the nurses perception regarding negative aspects of using technological devices in critical care units?

2. What is the impact of implementing guidelines on nurse's perception after implementation?

\section{SUBJECTS AND METHODS:}

Research Design: Quasi experimental research design was used in the current study to fulfill the aim of the study and answer the research questions.

\section{Setting:}

This study was conducted at general Intensive Care Units (ICU) and Cardiac Care Unit (CCU) of Port-Said General Hospital, El- Zohoor Hospital, Port Foad hospital, El-Mabarrah Hospital and El-Tadamon Hospital. A convenience sample was used in this study. The sample recruited in this study consisted of 112 nurses both-sexes genders (males and females) who were working in Intensive Care Unit and Cardiac Care Units at selected hospitals.

Tools of data collection: Structured questionnaire sheet tool was used in the study divided into two parts.

Part I: Socio-demographic Data Sheet: It was developed by the researcher, and included data related to age, gender, level of education, years of experiences and training courses on technological equipment... etc.

The tool was developed by researcher based on several lectures review adopted from (Noh et al., 2002; Kiekkas et al., 2006; Wikstrom et al., 2007; Samaher, 2008; Adel, 2014). 
Part II: questionnaire to assess negative aspects of using technology which divided into:

1. Negative aspects of use technology on patient such as (increased patient risk from improper handling of equipment, ignoring physical needs of patient...etc).

2. Complexity using technology such as (Nurse must be competent in managing technology and interpreting technological data, technology is complicate and not easy to handle...etc).

3. Negative aspect of use technology on nurse and nursing care such as (Increased nurse's psychological stress, technology restricts autonomy of nurses in making decision....etc)

The Interventional Nursing Perception Guidelines: The guidelines were designed based on several literature reviews and the findings of the baseline assessment of nurse`s perception regarding negative aspects of using technology in critical care units. It included the teaching guidelines schedule and illustrated booklet, PowerPoint, posters, and videos to achieve the general objectives of the program the guidelines included five educational sessions would be conducted for each nurse in addition to the pre assessment session.

(II) Operational Design: The Operational design includes preparatory phase and a pilot study

Preparatory Phase:It was included revision of related literature, and theoretical knowledge of various aspects of the study using books, articles, internet periodicals and magazines to develop the tools for data collection. The tool was tested for content validity by 7 expert nurse educators from the Faculty of Nursing in Ain shams University, Alexandria University and a second phase, to check for clarity.

Pilot Study: A pilot study was carried out after development of data collection tool. And it was applied on a sample of "9" nurses working in previously selected settings, and was conducted one month before embarking on the field of the working of the study. After obtaining the result of the pilot study, the necessary modifications were done and the final form was developed. The nurses in the pilot study were not included in the main sample.

Field of the Work: Data were collected from March 2015 to May 2016. Data were collected five days a week from Saturday to Thursday at morning shift from 8:00 Am 
to 2:00 pm and afternoon shifts from 2:00 $\mathrm{pm}$ to $8: 00 \mathrm{pm}$ and nurses were recruited conveniently. Data were collected through the following four phases:

- Phase I: Prior Guidelines Development: The researcher would started the preparation of the tools, which would be used from the different scientific references and then identify the nurses. This would be followed by collecting baseline data, which would help in the design of the guidelines, in addition to literature review.

- Phase II : Pre-Test Phase (Prior Guidelines Implementation): The researcher assessed the nurses' socio-demographic characteristics and perceptions of negative aspects regarding the use of technological devices in critical care units by using part I,II of tool

- $\quad$ Phase III: Implementation Phase: The guidelines would be implemented in a clear and concise manner in 5 sessions within 6 months.

- Phase IV: Evaluation Phase (Post-Test and Follow-Up): It would be assessed immediately after implementing and follow-up after 3 months of the guidelines implementation.

(III) Administrative Design: An official verbal and written permission to conduct the study was obtained from the head of Critical care units of the selected hospitals.

Ethical Considerations: The aim of the study has been explained to directors, physicians and staff nurses at critical care units of the concerned hospitals before asking them to participate in the study, stressing on confidentiality of the collected information.

\section{Statistical Design:}

- Data were extracted from the interview questionnaire and computerized in Microsoft Excel 2010. Analysis was undertaken using IBM SPSS (statistical package for social science) version 22.0.

- A significant level value was considered when $\mathrm{p}$-value $\leq 0.05$ and a highly significant level value was considered when $p$-value $\leq 0.001$, while $p$-value $>0.05$ indicates non-significant results. 


\section{RESULTS:-}

Table (1): shows that more than half of nurses in the study sample (58.0\%) were at age group less than 25 years old. Regarding years of experience, more than two fifths of nurses $(42.0 \%)$ had $1-5$ years of experience, while $(28.6 \%)$ of them had more than five year of experience. For nursing qualification, most nurses in the study sample $(83.9 \%)$ had a nursing school diploma.

Table (2): reveals that nurses in the studied sample were increased perceptions to negative aspects of using technology on patient and nurse throughout the phases with high statistical significant relation whereas $(\mathrm{p}=0.000)$. In contrast, the nurses in the studied sample weren 't increased perceptions to negative aspects of using technology concerning technology complexity. Also, the same table demonstrates a high percentage in total agree nurses perception of negative aspects when compared between pre- intervention (5.4\%), post-intervention (83.9\%) and follow up (84.8\%) with high statistically significant difference as $(\mathrm{p}=0.000)$.

Table (3): reveals that there were no statistically significant relations between nurses' pre-intervention perception related to the negative aspect of technology use and there socio-demographic characteristics.

Table (4): demonstrates that there were statistically significant relations between nurses' post-intervention perception related to the negative aspects about technology use and their gender. Moreover, indicates high statistically significant relations between nurses' post-intervention perception related to the negative aspect of technology use and their qualification

In multivariate analysis (Table 5), the intervention program was the main positive predictor of the change in nurses' negative perception score. The model explains $41 \%$ of the change in nurse's negative perception score. 
Table (1): Frequency distribution of the study sample according to their socio-demographic characteristics $(n=112)$

\begin{tabular}{|l|c|c|}
\hline Socio-demographic Characteristics & No & $\%$ \\
\hline Age & 65 & $58.0 \%$ \\
Less than 25 & 38 & $33.9 \%$ \\
$25-35$ & 9 & $8.0 \%$ \\
More than 35 & 13 & $11.6 \%$ \\
\hline Gender & 99 & $88.4 \%$ \\
Male & & \\
Female & 18 & $16.1 \%$ \\
\hline Qualification & 94 & $83.9 \%$ \\
Bachelor & 0 & $0 \%$ \\
Nursing school diploma & 12 & $10.7 \%$ \\
Health technical institute & 100 & $89.3 \%$ \\
\hline Position & & \\
Head Nurse & 33 & $29.5 \%$ \\
Staff Nurse & 47 & $42.0 \%$ \\
\hline Years of Experience (Year) & 32 & $28.6 \%$ \\
Less than 1 & & \\
$1-5$ & & \\
More than 5 & & \\
\hline
\end{tabular}


Table (2): Frequency distribution of nurses' total score upon the positive aspects of using technology throughout study phases $(\mathrm{n}=112)$

\begin{tabular}{|c|c|c|c|c|c|c|c|}
\hline \multirow{2}{*}{ Negative Aspects } & \multicolumn{2}{|c|}{ Pre } & \multicolumn{2}{|c|}{ Post } & \multicolumn{2}{|c|}{$\mathbf{F U}$} & \multirow{2}{*}{$\begin{array}{c}\mathrm{X}^{2} \\
\text { (P-value) }\end{array}$} \\
\hline & No & $\%$ & No & $\%$ & No & $\%$ & \\
\hline $\begin{array}{l}\text { Patients } \\
\text { Agree } \\
\text { Uncertainly } \\
\text { Disagree }\end{array}$ & $\begin{array}{l}12 \\
90 \\
10\end{array}$ & $\begin{array}{l}10.7 \\
80.4 \\
8.9\end{array}$ & $\begin{array}{c}96 \\
14 \\
2\end{array}$ & $\begin{array}{c}85.7 \\
12.5 \\
1.8\end{array}$ & $\begin{array}{c}98 \\
11 \\
3\end{array}$ & $\begin{array}{c}87.5 \\
9.8 \\
2.7\end{array}$ & $\begin{array}{c}182.35 \\
\mathrm{P}=0.000^{* *}\end{array}$ \\
\hline $\begin{array}{l}\frac{\text { Nurse }}{\text { Agree }} \\
\text { Uncertainly } \\
\text { Disagree }\end{array}$ & $\begin{array}{c}4 \\
61 \\
47\end{array}$ & $\begin{array}{c}3.6 \\
54.5 \\
42.0\end{array}$ & $\begin{array}{c}81 \\
23 \\
8\end{array}$ & $\begin{array}{c}72.3 \\
20.5 \\
7.1\end{array}$ & $\begin{array}{c}94 \\
11 \\
7\end{array}$ & $\begin{array}{c}83.9 \\
9.8 \\
6.3\end{array}$ & $\begin{array}{c}172.71 \\
\mathrm{P}=0.000^{* *}\end{array}$ \\
\hline $\begin{array}{l}\text { Technology complexity } \\
\text { Agree } \\
\text { Uncertainly } \\
\text { Disagree }\end{array}$ & $\begin{array}{c}7 \\
31 \\
74 \\
\end{array}$ & $\begin{array}{c}6.3 \\
27.7 \\
66.1 \\
\end{array}$ & $\begin{array}{c}6 \\
32 \\
74 \\
\end{array}$ & $\begin{array}{c}5.4 \\
28.6 \\
66.1 \\
\end{array}$ & $\begin{array}{c}6 \\
32 \\
74 \\
\end{array}$ & $\begin{array}{c}5.4 \\
28.6 \\
66.1 \\
\end{array}$ & $\begin{array}{c}0.126 \\
\mathrm{P}=1.0\end{array}$ \\
\hline $\begin{array}{l}\text { Total Score } \\
\text { Agree } \\
\text { Uncertainly } \\
\text { Disagree }\end{array}$ & $\begin{array}{c}6 \\
82 \\
24\end{array}$ & $\begin{array}{c}5.4 \\
73.2 \\
21.4\end{array}$ & $\begin{array}{c}94 \\
15 \\
3\end{array}$ & $\begin{array}{c}83.9 \\
13.4 \\
2.7\end{array}$ & $\begin{array}{c}95 \\
12 \\
5\end{array}$ & $\begin{array}{c}84.8 \\
10.7 \\
4.5\end{array}$ & $\begin{array}{c}193.64 \\
\mathrm{P}=0.000^{* *}\end{array}$ \\
\hline
\end{tabular}

Table (3): Relation between nurses' pre-intervention perception related to negative aspect of technology use and their socio-demographic characteristics $(n=112)$

\begin{tabular}{|c|c|c|c|c|c|c|c|c|}
\hline \multirow{3}{*}{$\begin{array}{c}\text { Socio-demographic } \\
\text { Characteristics }\end{array}$} & \multicolumn{6}{|c|}{ Total Score } & \multirow{3}{*}{$\mathbf{X}^{2}$} & \multirow{3}{*}{ p-value } \\
\hline & \multicolumn{2}{|c|}{ Agree } & \multicolumn{2}{|c|}{ Uncertain } & \multicolumn{2}{|c|}{ Disagree } & & \\
\hline & No & $\%$ & No & $\%$ & No & $\%$ & & \\
\hline $\begin{array}{l}\text { Age } \\
\text { Less than } 25\end{array}$ & 3 & 2.7 & 48 & 42.9 & 14 & 12.5 & \multirow{3}{*}{1.065} & \multirow{3}{*}{0.90} \\
\hline $25-35$ & 3 & 2.7 & 27 & 24.1 & 8 & 7.1 & & \\
\hline More than 35 & 0 & 0.0 & 7 & 6.3 & 2 & 1.8 & & \\
\hline Gender & & & & & & & \multirow{3}{*}{0.200} & \multirow{3}{*}{0.91} \\
\hline Male & 1 & 0.9 & 9 & 8.0 & 3 & 2.7 & & \\
\hline Female & 5 & 4.5 & 73 & 65.2 & 21 & 18.7 & & \\
\hline Qualification & & & & & & & \multirow{4}{*}{10.483} & \multirow{4}{*}{0.11} \\
\hline Bachelor & 3 & 2.7 & 11 & 9.8 & 4 & 3.6 & & \\
\hline Nursing school diploma & 3 & 2.7 & 71 & 63.4 & 20 & 17.9 & & \\
\hline Health technical institute & 0 & 0 & 0 & 0 & 0 & 0 & & \\
\hline
\end{tabular}

(**) high statistically significant at $\mathrm{p}<0.0$ 
Table (4): Relation between nurses' post-intervention perception related to negative aspect of technology use and their socio-demographic characteristics $(n=112)$

\begin{tabular}{|c|c|c|c|c|c|c|c|c|}
\hline \multirow{3}{*}{$\begin{array}{l}\text { Socio-demographic } \\
\text { Characteristics }\end{array}$} & \multicolumn{6}{|c|}{ Total Score } & \multirow{3}{*}{$\mathbf{X}^{2}$} & \multirow{3}{*}{ p-value } \\
\hline & \multicolumn{2}{|c|}{ Agree } & \multicolumn{2}{|c|}{ Uncertain } & \multicolumn{2}{|c|}{ Disagree } & & \\
\hline & No & $\%$ & No & $\%$ & No & $\%$ & & \\
\hline Age & & & & & & & \multirow{4}{*}{2.063} & \multirow{4}{*}{0.72} \\
\hline Less than 25 & 52 & 46.4 & 11 & 9.8 & 2 & 1.8 & & \\
\hline $25-35$ & 34 & 30.4 & 3 & 2.7 & 1 & 0.9 & & \\
\hline More than 35 & 8 & 7.1 & 1 & 0.9 & 0 & 0.0 & & \\
\hline \multicolumn{7}{|l|}{ Gender } & \multirow{3}{*}{9.307} & \multirow{3}{*}{$0.01 *$} \\
\hline Male & 10 & 8.9 & 1 & 0.9 & 2 & 1.8 & & \\
\hline Female & 84 & 75.0 & 14 & 12.5 & 1 & 0.9 & & \\
\hline \multicolumn{7}{|l|}{ Qualification } & \multirow{4}{*}{26.42} & \multirow{4}{*}{$0.000 * *$} \\
\hline Bachelor & 18 & 16.1 & 0 & 0.0 & 0 & 0.0 & & \\
\hline Nursing school diploma & 76 & 67.9 & 15 & 13.4 & 3 & 2.6 & & \\
\hline Health technical institute & 0 & 0 & 0 & 0 & 0 & 0 & & \\
\hline
\end{tabular}

(*) statistically significant at $\mathrm{p}<0.05$

(**) high statistically significant at $\mathrm{p}<0.01$

Table (5): Best fitting multiple linear regression model for the negative perception score

\begin{tabular}{||c|c|c|c|c|c|c|c||}
\hline & $\begin{array}{c}\text { Unstandardized } \\
\text { Coefficients }\end{array}$ & \multirow{2}{*}{$\begin{array}{c}\text { Standardized } \\
\text { Coefficients }\end{array}$} & \multirow{2}{*}{ t-test } & p-value & \multicolumn{2}{|c||}{$\begin{array}{c}\text { 95\% Confidence } \\
\text { Interval for B }\end{array}$} \\
\cline { 2 - 6 } & B & $\begin{array}{c}\text { Std. } \\
\text { Error }\end{array}$ & & & & Lower & Upper \\
\hline Constant & 60.57 & 1.00 & & 59.294 & $<0.001$ & 57.58 & 61.54 \\
\hline Intervention & 7.41 & 0.46 & 0.65 & 13.757 & $<0.001$ & 7.31 & 5.48 \\
\hline R-square $=0.174$
\end{tabular}

\section{DISCUSSION:}

The ICU environment deprives patients of normal sensory stimuli while bombarding them continuously with strange sensory stimuli. On the other hand, modern technology has enabled the use of new forms of information in the care of critically ill patients. In intensive care units (ICU), technology can simultaneously reduce the lived experience of illness and magnify the objective dimensions of patient care (Noh et al., 2002; Pang, \& Suen, 2008; Almerud et al., 2008; Hegland, 2012).

The majority of nurses included in the present study carried diploma degrees in nursing. This is a common finding in studies in Egypt, where the majority of the nursing workforce consists of diploma graduates (Ahmed, 2003; Booker, 2015). The nurse having a higher qualification is expected to have more perception regarding the use of technology in critical areas since the curricula of bachelor degree programs of 
nursing offer more time and depth to the theory and practice of this important subject. Hence, the nursing schools' curricula should incorporate concepts and principles that guide students in developing caring, safe, competent, and professional behavior (Khouri, 2011).

According results, the nurses' perception of negative aspects regarding the use of technological devices in critical care units was low at the pre-intervention phase of the study. This relatively low percentage of high perception might be result from complexity of critical care units and difficult providing support in most ICUs as the expert nurses tend to have a full care assignment that includes patients with the most medically complicated conditions. In congruence with this result Goran and Mullen (2012) revealed that, recommendation to improve the work environment of nurses included assigning experienced nursing staff to precept new-to-practice nurses to address knowledge and skill gaps.

However, Saperstein et al. (2009) revealed that, a survey of nurses` perceptions of first-job experiences revealed that, $30.0 \%$ of new-to-practice nurses leave within the first years, and over one-half leave within the first 2 years and they concluded that, stressful work environments that offered little support and guidance were cited as factors that influenced the nurses`decision leave.

Highly significant improvement in almost all areas of nurses' perception regarding to the negative aspects of using technological devices in critical care units. This was indicated that, the implementation of guidelines was very effective in enhancing nurses perception of technology. This is in agreement with research that indicated the overall score for nurses' competence in managing patient situations is in the "good" range. Those who attended a case review session had higher overall scores in eleven of the thirteen aspects of the study scale (Marie, 2013).

The present study results revealed highly significant improvement of negative aspects of using technological devices, especially related to the patient and nurse compared between pre and post intervention and during follow up. This reflects the effectiveness of the educational guidelines to clearly define the negative aspects, which affect on patient and nurse as a specific and on health care provided, as general and desired of nurses to understand the negative effects of using technology to protect the patient and protect themselves. 
On the same line, Buckner and Gregory (2011) who believed that, driven by an urgent need to improve the safety and quality of care provided in our increasingly complex health care system, health information technology has taken a central role in the health care system. These technologies have the potential to improve patient care while helping clinicians harness the explosive knowledge growth accelerating us into the 21 st century. The technology used at the point of care undoubtedly changes the process of nurse and patient interactions because caring is a core value in nursing and the human interactions between nurse and patient are now occurring in the midst of a myriad of new technologies, these questions seem vital to maintaining the critical care nurse's identity as patient-centered care provider.

The relation between received training on each technological equipment as individual and perception regarding negative aspects of using technology were no statistically significant. Worth noting that no statistically, significant differences between nurses had training and nurses had not trained. This is may be related to training is not qualified and may have defected because the majority of nurses in the study sample reflect a problem in training and concentrated on nurse's complains on training like "lack of regular nurses opportunities and traditional use of training method and media" leaded the nurse to refuse this training. In the same time must take in consideration shortage of nursing because this is lead to refuse the training to compensate the shortage.

The present study result provided an objective evidence of the success of the training intervention in achieving its ultimate goal, which indicated training intervention related to negative aspects of using technological devices in critical care units changes nurses` perception by (41.0\%). This is good average of change when take in consideration face of factors affected training in real situations; it was preferred previously.

\section{CONCLUSION:}

\section{From this study, it can be concluded that:}

- There was statistically high percentage in the total score of perception related to negative aspects when compared between pre-intervention, post-intervention, and follow up with high statistically significant differences.

- The impact of guidelines on nurses` perception regarding the use of technological 
devices in critical care units would be benefited.

\section{RECOMMENDATIONS:}

Based on the result of this study the following recommendations are suggested:

Recommendations for Nursing Practice:

(1) Improve and update the Nurses' knowledge about negative aspects of using technology in critical care units through, Encourage nurses to attend regular, formal in-service education.

(2) Specific books, handouts and slides include comprehensive information about technological devices in Arabic language should be available and developing training materials.

\section{Recommendations for Nursing Educational (undergraduate and continued):}

- Nursing curriculums must include concept of technological devices in critical care units which include knowledge and skills about technology, with great emphasis on application through adequate training.

\section{Recommendations for Future Studies:}

- An ongoing, well-structured education program for nurses about positive and negative aspects of using technology should be initiated in critical care units.

\section{REFERENCES:-}

Adel, L. (2014): Nurses` perception regarding the use of technological devices in critical care units. IOSR Journal of Nursing and Health Science (IOSR-JNHS), eISSN: 2320-1959.p- ISSN: 2320-1940, 3(5), 11-18.
Ahmed, H. (2003): Assessment of nurses' knowledge and practice about postoperative wound infection. Master Dissertation, Faculty of Nursing, Suez Canal University. Egypt.
Almerud, S., Alapack, R., Fridlund, B., \& Ekeberg, M. (2008): Beleaguered by technology: care in technologically intense environments. Nursing Philosophy, 9(1), $55-61$.

Booker, K. (2015): Critical care nursing: monitoring and treatment for advanced nursing practice. ISBN: 978-0-470-95856-8, published by john Wiley and sons Inc. 
Buckner, M., \& and Gregory D (2011): Point-of-care technology: preserving the caring environment. Critical care nursing Quarterly, 34(4), 297-305.

Elizabeth A (2010): Patient safety technology: AACN Advanced Critical Care Volume 20, Number 2, pages 128-132.

Goran, S., \& Mullen, M. (2012): Partnership for a healthy work environment. AACN advanced critical care, 23(3), 289-301.

Gralton, J., Rawlinson, D., McLaws, L., \& Trop, D. (2013): Health care workers' perceptions predicts uptake of personal protective equipment. AJIC, 41(1), 2-7.

Hegland, L. (2012): Advanced ICU care`s tele-ICU program is one of the easiest decisions a hospital will ever have to make. Source, link Accessed at 1-2-2016.

Hweidi, I. (2007): Jordanian patients` perception of stressors in critical care units: A questionnaire survey. International journal of nursing studies, 44, 227-235.

Khouri, R. (2011): Impact of an educational program on nursing students' caring and self-perception in intensive clinical training in Jordan. Advances in medical education and practice, 2(1), $173-185$.

Kiekkas, P., Karga, M., Poulopoulou, M., Karpouhtsi, I., Papadoulas, V. and Koutsojannis, C. (2006): Use of technological equipment in critical care units: nurses` perceptions in Greece. Journal of clinical nursing; 15(2):178-87.

Marie, D. (2013): Nurses perceptions of their competence in managing patient situations in acute care. Open access dissertations by DigitalCommons@URI.Paper13

Noh C, Arthur D and Sohng K (2002): Relationship between technological influences and caring attributes of Korean nurses. International journal of Nursing Practice; 8(5):247-56.

Pang, P., \& Suen, L. (2008): Stressors in the ICU: a comparison of patient's and nurses` perception. Journal of Clinical Nursing; 17(20), 2681-9.

Puri, N., Puri, V. \& Dellinger, R. (2009): History of technology in the intensive care units. Crit care clin, 25(1), 185-200. 
Samaher, L. (2008): Nurses' Perception Regarding the Use of Technological Equipment in the Critical Care Units. Journal of American Science, published 2011; 7(10):545-552]. (ISSN: 1545-1003).

Saperstein, A., Lone, N., Latif, A., Fackler, J., \& Pronovost, P. (2009): Tele-ICU: paradox or panacea? Best Pract Res Clin Anaesthesiol, 23(1), 115-126.

Sole, M., Klein, D., \& Moseley, M. (2013): Introduction to critical care nursing. $6^{\text {th }}$ ed, Philadelphia, WB Saunders Co, 3-67, 201-216, 461-470.

Webster, M. (2016): Definition of technology and perception. The best dictionary available for English learners. Merriam-Webster's Advanced Learner's English Dictionary. Available at: http://www.merriam-webster.com/. Accessed at: 1-7-2016.

White, J. (2016): Two ways technology is improving ICU patients` care and experience. Available at: http://www.healthcarebusinesstech.com/technology-icupatients. Accessed at: 1-7-2016.

Wikstrom, A. (2007): Knowing in practice at tool in the production of intensive care. Printed in Sweden by intellect a docusys AB vastra frolunda 2007. ISBN131978-91628-7173-4. 
تقيم ادراك الممرضات تجاه استخدام الاجهزة التكنولوجيه بوحدات الرعايه الحرجه

لارا عادل ، أ.د. ماجده عبد العزيز محمد ،أد. ممدوح محمد المزين، د. دينا التابعى صبح صبيح

أخصائي تدريس علوم تدريض بالدعه الفنى الصحى ببورسعبي، استاذ التصريض الباطنى والجراحى كلبة

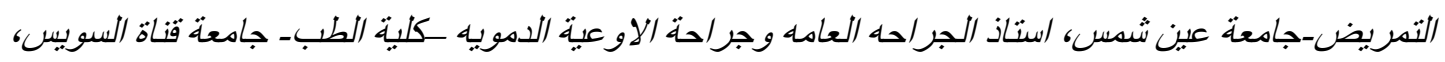
مدرس التهريض الباطنى والجر/حى كلية التصريض- جامعة بورسعبد

\section{الخلاصة}

أجريت هذه الدر اسة ذات التصميم شبه التجريبي لتقييم تأثير تطبيق الإرشـادات على إدر اك الممرضين تجاه استخدام الأجزةة التكنولوجية فى وحدات العناية الحرجة بمستشفى بوسعيد العام، الزهور العام، بورفؤاد العام، ومستشفى التامين الصـي (المبرهـ التضـامن) على عينـة قو امها 112 ممرض وض ممرضـة مـن العاملين بوحدات

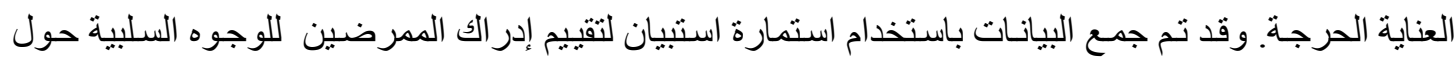
استخدام الأجززة التكنولوجية في وحدة العناية الحرجة وتتشل :الجزء الأول ويتكون مسن: البيانات الثخصية و الأجتماعية مثل (السن ، المؤهل.....) الجزء الثاني: استمارة استبيان لتقييم إدر الك الممرضـة للنواحى السلبية حول إستخدام الأجزةة التكنولوجية فى وحدة العناية الحرجة و الني تشمل: النواحي السلبية لإستخدام التكنولوجية على المريض مثل ( يزيد من الخطر على المريض نتيجة أخطاء أفر اد الفريق الصحي، بسـاعد على تجاهل

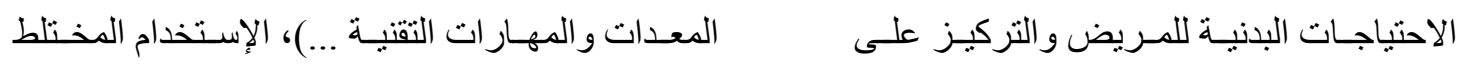
للتكنولوجية مثل ( يجب أن تكون الممرضة على كفاءة عالية فى تدبير الأجهزة التكنولوجية و تفسير المعلومـات

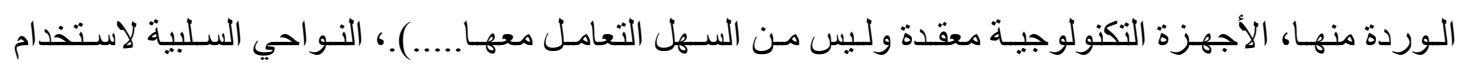

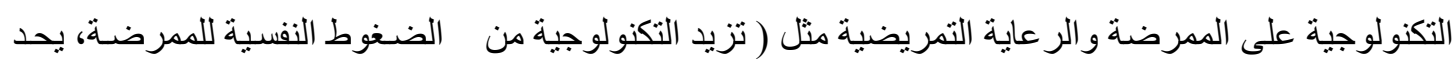
استخدام التكنولوجية من الحرية الذاتية للممرضة في إتخاذ القرار..........).

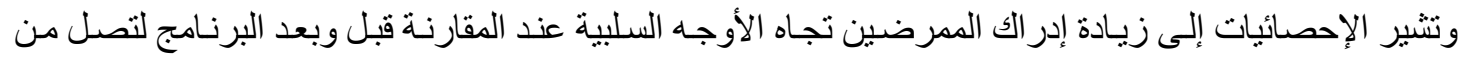
(5.4\%) قبـل البرنـامج إلى (83.9\%) بعـد البرنـامج ثم (84.8\%) خـلال المتابعه ،كمــاتوجد علاقـة ذات دلالـة

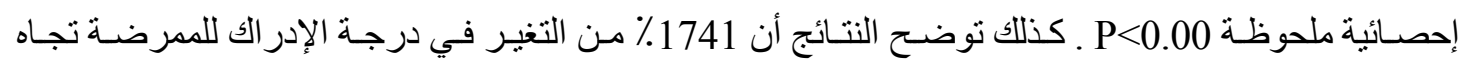
الجو انب السلبيه و هذا يوضح أن التحسن كان ملحوظ تجاه الأوجه السلبية لكنه لم يترجم إلى تغير فى السلوك تجاه

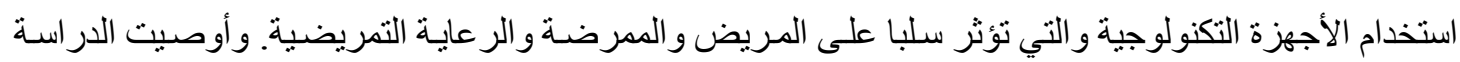

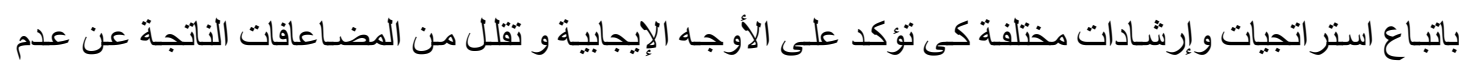

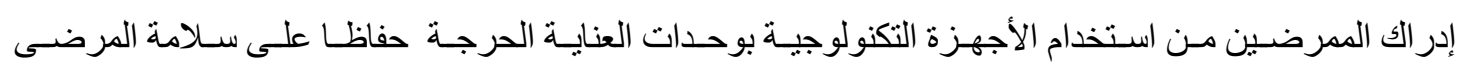

و الممرضين بتلك الوحدات.

الكلمات المرشده: وحدات الرعاية الحرجهـ ارشادات ـ إدر اك ـ الوجوه السلبية ـ التكنولوجيا 